\title{
Recognition of Patterns of Failures through Elements of the Fuzzy Logic
}

\author{
Hidalgo Elio ${ }^{1}$, Perez-Rodriguez Roberto², Trinchet Carlos ${ }^{3}$, Vargas Javier ${ }^{4}$, Isaza Lauren ${ }^{5}$ \\ ${ }^{1}$ CAD-CAM Study Center, University of Holguin-Cuba. \\ ${ }^{2}$ CAD-CAM Study Center, University of Holguin-Cuba. \\ ${ }^{3}$ CAD-CAM Study Center, University of Holguin-Cuba. \\ ${ }^{4}$ GIPIS Research Group. Cooperative University of Colombia. \\ ${ }^{5}$ GIMEC Research Group. Faculty of Mechanical Engineering. University of Santo Tomas. \\ ORCID: 0000-0001-6208-8659 (Javier Vargas)
}

\begin{abstract}
Different methods for the recognition from patterns exist, in article appears the recognition of patterns through the use of fuzzy membership functions, elaborated for the case of study, and elements of the fuzzy logic. The shown procedure contains four steps that they initiate in the data collection, the fuzzyfication, the calculation of the coincidence probability and the desfuzzyfication step that defines the patterns of failures in the analyzed motor of internal combustion. It was possible to be verified that the variables Tf (temperature of the fuel), Pf (pressure of the fuel) and Pai (pressure of the air), are altered before the sprouting of the studied failures, modifying his values and indicating different symptoms from incipient failures and that the patterns of failures, for each one of the three mentioned variables, settle down between the values limits according to the characteristics of each variable and following the behavior described by the developed functions of property.
\end{abstract}

Keywords: pattern of failure, fuzzyfication, desfuzzyfication, fuzzy logic.

\section{INTRODUCTION}

The use of techniques such as optimization, artificial intelligence, fuzzy logic, computational arithmetic, among others, allow the development of technologies and analysis that contribute to the management of industrial maintenance, so the detection and diagnosis of failures has a very important role in many industrial areas in which engineering intervenes[1] [2].

This complexity appears by the great number of variables that take part in the industrial processes and that are due to take into account at the time of their observation. Therefore it is a challenging and difficult task, the power to identify the variables that are outside the normal conditions of operation within a process that is being observed [3] [4].
In [5] [6] [7] raise the necessity and the importance of the diagnosis of failures to maintain the processes in a state of safe operation that they allow to preserve the production, the human life and the ambient.

For the methods based on the data one is due to count with an ample amount of historical data of the process. There are different ways into that these data can be transformed and process to obtain useful data that allows characterizing an abnormal behavior or fails [8] [9] [10].

This process is known as extraction knowledge and can be classified of general form in statistical methods multivariate and automatic methods of recognition of patterns.

The great set of techniques and methodologies that allow exploring set of data of automatic way, with the objective to identify patterns, tendencies or rules, are grouped in a great well-known area like the mining of data. Within the context of the methods it dates-driven the mining from data offers to the tools adapted for the processes of detection and isolation of faults, which in their majority already have been evaluated and proven successfully in another type of applications [9] [11].

In [12] raise the following thing: the recognition of patterns is a scientific discipline that classifies to the objects in categories or classes. The recognition of the pattern is also an integral of most of the intelligent systems, existing part in the machines, constructed for the decision making.

When a system presents deviation, that it prevents him to work according to the intention for which it was designed, in [13] said that has happened a failure. A general vision of the techniques that have been developed to approach this problematic one classifies in three great groups: the methods based on qualitative models, the methods based on quantitative models and the methods based on historical of the process [14].

The approach based on recognition of patterns subdivides in which they use the tools of the artificial intelligence (AI) and those that make an analysis statistical of the historical data. Of 
general form, the methods that use this approach, AI, are easy to implement, they do not need a mathematical model and they require little a priori knowledge of the parameters of the process. These characteristics constitute an advantage in very complex systems, where the relations between variables are nonlinear or strangers and where it is very difficult to determine an analytical model that it describes to the dynamics of the process of efficient form [13] [15].

According to [14], some of them can be: Nearest Neighbors (NN), Partial Minimums (PM) and Artificial Neuronal Networks (ANN). These authors conclude that the most powerful tools and of great power of generalization to classify the failures are the artificial neuronal networks. The authors raising that the Nearest Neighbors and Partial the Square Minimums have little power of generalization and low success in the classification of the failures in the industrial processes.

According to [10], a pattern is an organization to which a name can be given him like for example, an image of fingerprint, a word, a signal of voice, a fault, among others.

[17] it outlines that the recognition of patterns is a science that descends from the branch of the artificial intelligence that is in charge of the description and classification (recognition) of objects, people, representations of everything what interacts with the human being and who in the end can be represented of digital form. The author continues raising who with the aid of the recognition of patterns nowadays can be given a guessed right diagnosis more.

The investigator defines for the work as pattern of functional failure to the value or interval of values that allows to know the sprouting the possible failure in an equipment.

[18] show a system of recognition of patterns has one of the following objectives: to identify the pattern like member of a class or defined (supervised classification) and to assign the pattern to a class still not defined (classification no supervised, group or clustering).

The design of a system of recognition of patterns is normally carried out in three phases: acquisition and preprocess of data, extraction of characteristics and decision making or group.

[19] Show the fuzzy logic arises like alternative to the classic logic, allowing to treat vague information with which many of the phenomena of the daily life can be described. By means of the fuzzy logic it is possible in addition to be fought with any type of ambiguity and uncertainty and the systems that use this tool usually are fast and cheap due to the simplicity of their calculations. This theory allows to model processes nonlinear.

The present article is organized of following way: section 2 discusses the materials, methods and the methodology to follow together the mathematical formulations. Section 3 results and data processing. Section 4 talks about the main conclusions of the work.

\section{METHOD}

In order to develop the investigation whose results are exposed in this article they used theoretical methods of investigation as they are: analysis and historical synthesis and logical for the study of the object through the time and to arrive at a logical analysis.

The techniques used in the harvesting of the data were: participant observation, official documents of the company: technical files, internal registries of maintenances, documents and personal documents of preceding bibliographical revisions. Passages for the recognition

1. Data collection.

2. Fuzzyfication of the real data:

2.a To establish the fuzzy membership functions for each variable.

2.b To calculate the degrees of property (DP) of the value of the variable in the diffuse set.

3. To calculate the probability of coincidence (PC) of each variable with the occurrence of the failures through. Equation (1).

$$
\mathrm{PC}=\sum_{\mathrm{i}=1}^{\mathrm{N}} \frac{\overline{\mathrm{Vi}}}{\mathrm{N}} \cdot 100
$$

Where:

$$
\overline{\mathrm{V}} \mathrm{i}=1-\mathrm{DP}
$$

-Complement of the degrees property.

$\mathrm{N}$ - amount of failures.

\section{Defuzzyfication:}

4.a To look for the interval of confidence for the set of values (numbers fuzzy) of the variable of greater probability of coincidence with the occurrence of the failures.

4.b To replace the interval in inverse of the function of defined property variable it and to calculate the pattern of failures.

\section{RESULTS}

The variables of studied diagnosis of diagnosis are the following ones: oil pressure, temperature of the oil, temperature of the cooling liquid, pressure of the air, temperature of the air of the turbo compressor, temperature of the cooling liquid of the air of the turbo compressor, pressure of the fuel and temperature of the fuel, these variables for the study have been denoted with the first letters of the name of the variable, for example oil pressure (Op). The harvesting of the data is transformed in table 1 . 
The fuzzyfication of the data is made through the functions that are described next. In figure 1 is to the fuzzy membership functions of Left Triangular_ 1 for the variable pressures.

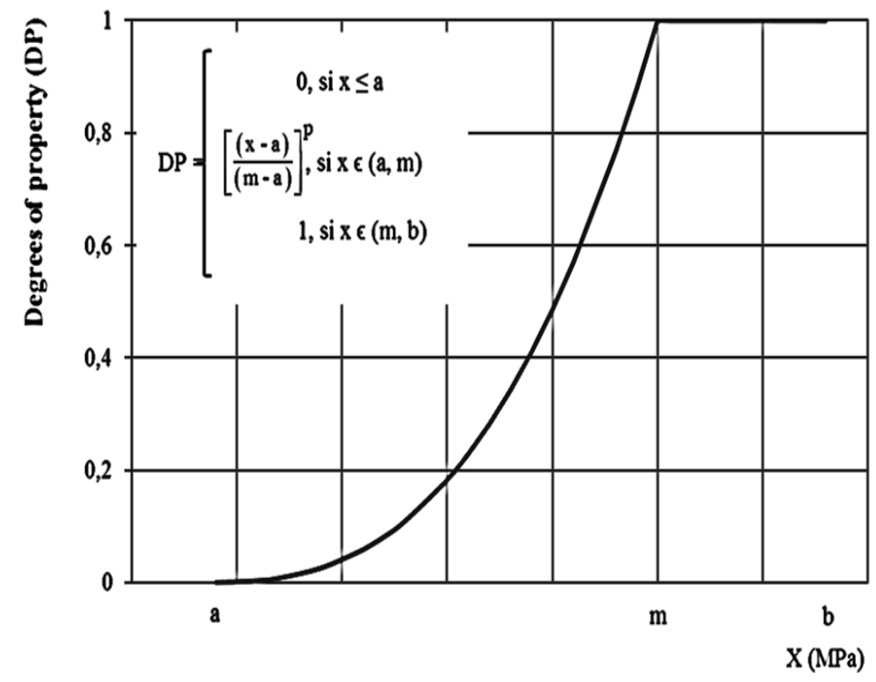

Figure 1: Membership function of Left Triangular_1

This function anticipates for the three variable pressures to locate between $\mathrm{m}$ and $\mathrm{b}$ the normal values of work of each one of them such receiving the maximum rank of property in each diffuse set.

The minimum value or inferior limit (IL) of each variable will be located in the point to and zero degree will always reach the smaller degree of property of the diffuse set. The located values of these variables of diagnosis that locate between the inferior limit and the smaller value of the normal values, point $\mathrm{m}$, from the same ones will receive ranks of property between 0 and 1 .

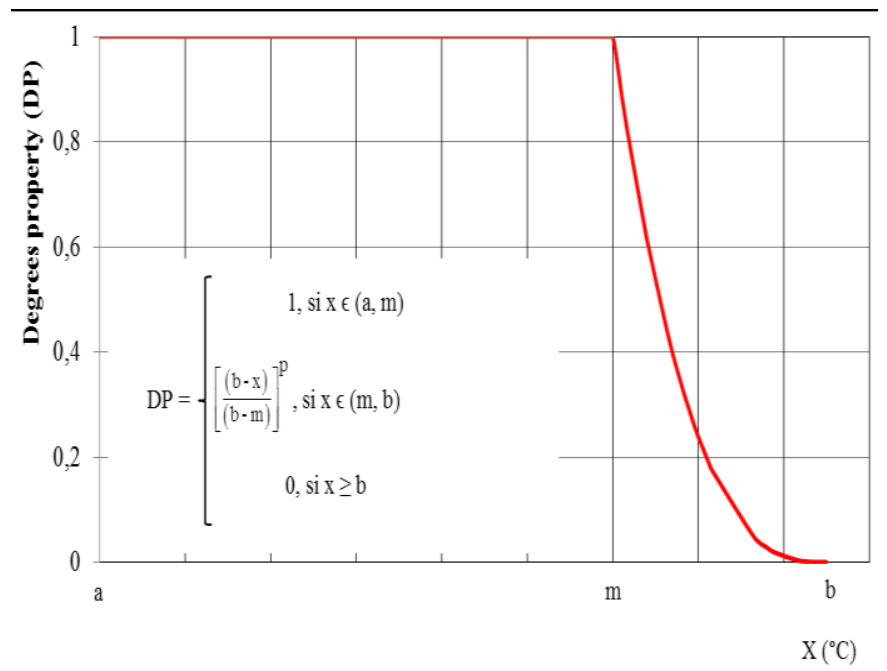

Figure 2 represents the fuzzy membership functions 1_Triangular

Right for the variable temperatures.This membership functions elaborated for the five variables of temperature has the following characteristics: the maximum degree of property of the values of the variables is obtained in the diffuse set when the variables take the normal values defined by the owner, the smaller degree of property is taken when the values of the variables arrive or pass the superior limit (SL) of each one of them and when the values of the variables locate between the superior limit and the greater value of the limit, point $\mathrm{m}$, defined by the owner as of normal work of the variable degrees of property between 0 and 1 are obtained.

In table 2 the degrees of property of the values of the variables in the established functions of property for each one of them are located.

In figure 3 the probabilities of coincidence (PC) of the values of the variable eight of diagnosis and the occurrence of the failures in the equipment.

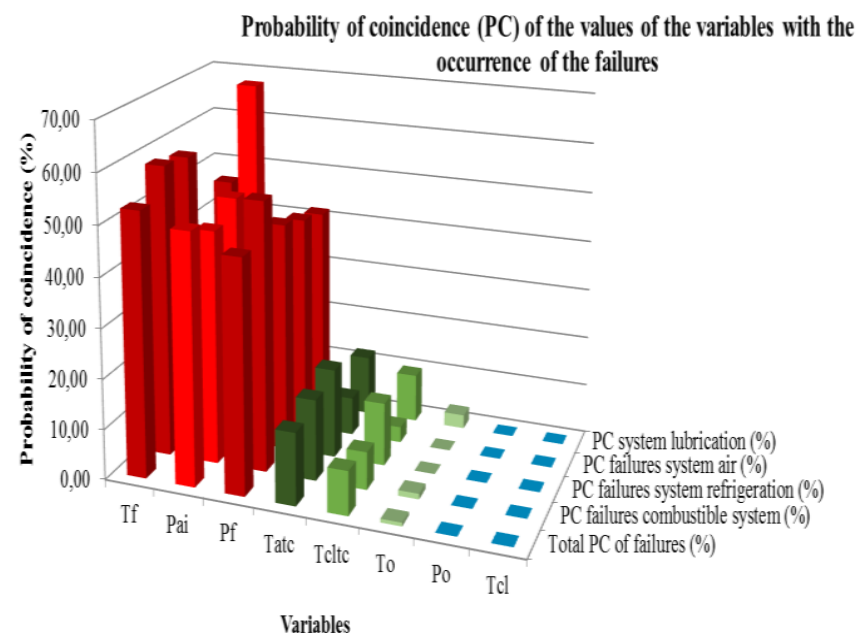

Figure 3: Probability of coincidence (PC \%) of the variables and the failures.

Of the calculation of the coincidence probability (PC) one concludes:

1. The probability of coincidence of the variables Tf, $\mathrm{Pf}$ and Pai with the occurrence of failures is high in five occasions.

2. The probability of coincidence of the variables temperature of the air (Tatc) and temperature of the cooling liquid of the air (Tcltc) is always located below $20 \%$.

3. The variable temperature of the oil in three occasions is located between $(0,5$ and 3$) \%$ and at two moments reaches $0 \%$ of coincidence probability.

4. The variables Po (oil pressure) and Tcl (temperature of the coolant) in the five occasions obtain $0 \%$ of coincidence probability.

5. That the values of three variables Tf, Pf and Pai are related strongly, under the conditions of operation in Cuba, with the sprouting of the failures in this equipment. 
International Journal of Engineering Research and Technology. ISSN 0974-3154, Volume 13, Number 9 (2020), pp. 2100-2105

(C) International Research Publication House. https://dx.doi.org/10.37624/IJERT/13.9.2020.2100-2105

The inverse ones of the property functions,

$\mathrm{x}=\left\lfloor\mathrm{DP}(\mathrm{X})^{1 / \mathrm{p}} \cdot(\mathrm{m}-\mathrm{a})\right\rfloor+\mathrm{a}$

$\mathrm{x}=\mathrm{b}-\left[\mathrm{DP}(\mathrm{X})^{1 / \mathrm{p}} \cdot(\mathrm{b}-\mathrm{m})\right\rfloor$

They allow to make the Defuzzyfication process and to know the patterns failures for each one of the variables determined like of greater probability of coincidence. In table 4 they locate the pattern of failures for each one of the variables previously analyzed (temperature and pressure of the fuel and pressure of the air).

Table 1: Values of the variables.

\begin{tabular}{|c|c|c|c|c|c|c|c|c|c|c|}
\hline Registry & Dates & Failure & Op & To & Tcl & Pai & Tatc & Tcltc & Pf & Tf \\
\hline 1 & $29 / 01 / 2012$ & 0 & 0,56 & 83,2 & 77,9 & 0,26 & 47,1 & 47,4 & 0,44 & 43,0 \\
\hline 2 & $29 / 01 / 2012$ & 0 & 0,55 & 85,4 & 78,9 & 0,26 & 49,0 & 48,7 & 0,41 & 52,3 \\
\hline 3 & $29 / 01 / 2012$ & 1 & 0,55 & 85,4 & 79,0 & 0,26 & 48,7 & 48,7 & 0,41 & 63,0 \\
\hline 4 & $31 / 01 / 2012$ & 0 & 0,54 & 85,4 & 78,6 & 0,27 & 44,5 & 43,3 & 0,57 & 44,3 \\
\hline 5 & $01 / 02 / 2012$ & 0 & 0,54 & 85,4 & 79,0 & 0,27 & 45,4 & 44,0 & 0,57 & 51,6 \\
\hline 6 & $03 / 02 / 2012$ & 1 & 0,54 & 85,4 & 79,0 & 0,26 & 45,6 & 44,4 & 0,60 & 44,5 \\
\hline 7 & $08 / 02 / 2012$ & 0 & 0,55 & 81,5 & 76,9 & 0,25 & 46,2 & 45,2 & 0,55 & 54,6 \\
\hline 8 & $09 / 02 / 2012$ & 0 & 0,55 & 82,4 & 77,9 & 0,25 & 49,0 & 48,4 & 0,55 & 54,7 \\
\hline 9 & $10 / 02 / 2012$ & 1 & 0 & 0 & 0 & 0 & 0 & 0 & 0 & 0 \\
\hline
\end{tabular}

Table 2: Degrees of property of each one of the variables in the function

\begin{tabular}{cccccccccccc}
\hline Registry & Date & Failure & Op & To & Tcl & Pai & Tatc & Tcltc & Pf & Tf \\
\hline 1 & $29 / 01 / 2012$ & 0 & 1 & 1 & 1 & 1 & 0,76 & 0,82 & 0,03 & 1 \\
2 & $29 / 01 / 2012$ & 0 & 1 & 1 & 1 & 1 & 0,57 & 0,68 & 0,00 & 0,31 \\
3 & $29 / 01 / 2012$ & 1 & 1 & 1 & 1 & 1 & 0,60 & 0,68 & 0,00 & 0 \\
4 & $31 / 01 / 2012$ & 0 & 1 & 1 & 1 & 1 & 1 & 1 & 0,66 & 1 \\
5 & $01 / 02 / 2012$ & 0 & 1 & 1 & 1 & 0 & 0,95 & 1 & 0,66 & 0 \\
6 & $03 / 02 / 2012$ & 1 & 1 & 1 & 1 & 1 & 0,93 & 1 & 1 & 1 \\
7 & $08 / 02 / 2012$ & 0 & 1 & 1 & 1 & 1 & 0,85 & 1 & 0,49 & 0,00 \\
8 & $09 / 02 / 2012$ & 0 & 1 & 1 & 1 & 1 & 0,57 & 0,71 & 0,49 & 0,02 \\
9 & $10 / 02 / 2012$ & 1 & 0 & 0 & 0 & 0 & 0 & 1 & 0 & 1 \\
\hline
\end{tabular}


International Journal of Engineering Research and Technology. ISSN 0974-3154, Volume 13, Number 9 (2020), pp. 2100-2105

(C) International Research Publication House. https://dx.doi.org/10.37624/IJERT/13.9.2020.2100-2105

Table 3: Conclusions of the analysis.

\begin{tabular}{ccccc}
\hline Variables & Pattern of failures & Type of failure & Elements of the internal combustion engine \\
\cline { 3 - 4 } $\begin{array}{c}\text { Temperature } \\
\text { fuel (Tf) }\left({ }^{\circ} \mathrm{C}\right)\end{array}$ & 47,6 & 52,5 & $\begin{array}{c}\text { Defective injector, low combustible, } \\
\text { loss of fuel and cooling liquid, } \\
\text { damaged radiator, high temperature of } \\
\text { the coolant }\end{array}$ & $\begin{array}{c}\text { Injector, pump of high pressure of the fuel, } \\
\text { radiator, heat exchanger }\end{array}$ \\
$\begin{array}{c}\text { Pressure fuel } \\
\text { (Pf) }(\mathrm{MPa})\end{array}$ & 0,48 & 0,56 & $\begin{array}{c}\text { Low pressure of the air and obstruction } \\
\text { in the fuel filter }\end{array}$ & $\begin{array}{c}\text { Fuel and air cleaner, lack of air tightness of } \\
\text { the fuel system }\end{array}$ \\
$\begin{array}{c}\text { Pressure of the } \\
\text { air (Pai) }(\mathrm{MPa})\end{array}$ & 0,24 & 0,25 & Dirty air cleaner and black smoke & Air cleaner and turbo compressor \\
\end{tabular}

\section{CONCLUSIONS}

It was possible to be verified that the variables $\mathrm{Tf}$ (temperature of the fuel), Pf (pressure of the fuel) and Pai (pressure of the air), are altered before the sprouting of the studied failures, modifying his values and indicating different symptoms from failures, such as the black smoke-screening, loss of fuels, low pressure of the air and the fuel, among others.

The patterns of failures, for each one of the three mentioned variables, settle down between the values limits according to the characteristics of each variable and following the behavior described by the developed and applied functions of property in the present investigation, thus for temperature of the fuel between $(47,6$ and 52,5$){ }^{\circ} \mathrm{C}$, for the pressure of the fuel between $(0,48$ and 0,56$) \mathrm{MPa}$ and for the pressure of the air between $(0,24$ and 0,25$) \mathrm{MPa}$.

The patrons of failures settled down for the variables, they allow knowing the operator, technician and manager the sprouting of failures process; this knowledge will allow making opportune decisions in the correction from the failures.

\section{REFERENCES}

[1] Diaz, E. Trinchet, C. \& Vargas, J. Design and simulation of a spiral hydraulic pump based on multiobjective optimization, ARPN Journal of Engineering and Applied Sciences, 15 (5), 657-663,2020.

[2] Velasquez, F., Vargas, J., \& Puente, S. (2017). Implementation of addition and doubled of a point on a curve in a field Edwards binary. Prospectiva, 15(2), 3339.

[3]. Q. Liu, C. Zhang \& A.C. Lin (1998) Pattern recognition of machine tool faults with a fuzzy mathematics algorithm, International Journal of Production Research, 36:8, 2301-2314, DOI: 10.1080/002075498192913

[4]. HERNÁNDEZ MORALES, C. O.; NIETO GONZÁlEZ, J. P.; CARRUM SILLER, E. G.
"Detección y diagnóstico de fallas en sistemas eléctricos de potencia (SEP) combinando lógica difusa, métricas y una red neuronal probabilística". Research in Computing Science 72, pp. 47-59. 2014.

[5] HURTADO CORTÉS, L. L.; VILLARREAL LÓPEZ, E.; VILLARREAL LÓPEZ, L. "Fault detection and diagnosis through artificial intelligence techniques, a state of art”. DYNA 83 (199), pp. 19-28, 2016.

[6]. LLANES SANTIAGO, O.; PRIETO MORENO, A.; CAMPS ECHEVARRIA, L.; BERNAL DE LÁZARO, J. M. “Aplicaciones de Inteligencia Artificial y Minería de Datos a Diagnóstico de Fallos y Estimación de Parámetros". Comunicación Corta Premio ACC 2015.

[7]. Zamarrón, A., Rodríguez, S. "Diagnóstico de fallas en el Motor de Inducción usando Lógica Difusa". Revista Iberoamericana de Ciencias. Marzo 2015 www.reibci.org. ISSN 2334-2501.

[8] Entezami, M., Hillmansen, S., Weston, P., \& Papaelias, M. P. (2012). Fault detection and diagnosis within a wind turbine mechanical braking system using condition monitoring. Renewable energy, 47, 175-182.

[9] Limas, P. Trinchet C. Almaguer P. Vargas, J and Isaza, L. Numerical Evaluation of the TensionalDeformational State of the Blade in the Gamesa G52/850 Wind Turbine During the Action of Extreme Wind. Journal of Engineering and Applied Sciences, 14: 3371-3377. Asian Journal of Information Technology, 18: 250-260. 2019 DOI: $10.36478 /$ jeasci. 2019.3371.3377

[10] MANRIQUE, R.F. "Detección y diagnóstico de fallas en turbinas de viento usando técnicas de minería de datos". Director: Dr.C Jorge Sofrany Esmeral. Tesis de máster en sistemas y computación. Universidad Nacional de Colombia. 2012.

[11] Al Ahmar, E., Choqueuse, V., Benbouzid, M. E. H., Amirat, Y., El Assad, J., Karam, R., \& Farah, S. (2010, September). Advanced signal processing techniques for fault detection and diagnosis in a wind turbine 
induction generator drive train: A comparative study. In 2010 IEEE Energy Conversion Congress and Exposition (pp. 3576-3581). IEEE.

[12] LIU, J.; SUN, J.; WANG, S.: "Pattern recognition: An overview", International Journal of Computer Science and Network Security, Vol.6 No. 6, Junio 2006. pp. 57 a la 61 .

[13] RODRÍGUEZ RAMOS, A.; LLANEZ SANTIAGO, O. "Diagnóstico de fallos en un generador de vapor BKZ 340-140 - 29M utilizando herramientas de lógica difusa”. Revista Ingeniería Mecánica. En línea. 2014. Vol. 17, No. 2, mayo - agosto, pp 147 - 156. ISSN 1815 - 5944.

[14] Calvo, R. A., \& D'Mello, S. (2010). Affect detection: An interdisciplinary review of models, methods, and their applications. IEEE Transactions on affective computing, 1(1), 18-37.

[15] Mellit, A., \& Kalogirou, S. A. (2008). Artificial intelligence techniques for photovoltaic applications: A review. Progress in energy and combustion science, 34(5), 574-632.

[16] BERNAL DE LÁZARO, J.M.; PRIETO MORENO, A.; LLANES SANTIAGO, O.; GARCÍA MORENO, E. "Estudio comparativo de clasificadores empleados en el diagnóstico de fallos de sistemas industriales". Revista Ingeniería Mecánica. 2011. Vol.14, No. 2, mayo agosto, pp 87 - 98. Consultado el: 12/12/15. Disponible en: http://www.ingenieriamecanica.cujae.edu.cu ISSN $1815-5944$.

[17] ANTONIO VELÁZQUEZ, J.A.; ALEJO ELEUTERIO, R.; LÓPEZ GONZÁLEZ, E.; GIL ANTONIO, L.; VALDOVINOS ROSAS; R.M. "Investigaciones actuales relacionadas al reconocimiento de patrones". Revista Aristas: Investigación Básica y Aplicada. ISSN 2007-9478, Vol. 4, No. 7. Año 2015.

[18] AlONSO ROMERO, L; CALONGE CANO, T. Capítulo 1. Redes Neuronales y Reconocimiento de Patrones. III Taller AIRENE sobre Reconocimiento de Patrones con Redes Neuronales. Braga, Portugal, 2001.

[19] DOMÍNGUEZ ACOSTA, C.; RODRÍGUEZ RAMOS, A.; LLANES SANTIAGO, O. "Diagnóstico de fallos múltiples mediante el uso de sistemas difusos y la transformada de Wavelet". XVI Convención de Ingeniería Eléctrica, CIE- 2015. CUJAE, La Habana, 2015 . 